\title{
MISFEASANCE IN PUBLIC OFFICE, GOVERNMENTAL LIABILITY, AND EUROPEAN INFLUENCES
}

\author{
Mads ANDENas* And Duncan FaIRGRIEVE**
}

\section{INTRODUCTION}

The protection offered to individuals by remedies in public law and tort law is developing in all jurisdictions. The past few years have witnessed an increasingly important European dimension to the tort liability of public authorities. European Union law and European Human Rights law have added to the constitutional protection of tort claims against public authorities already established as a matter of domestic law in many European countries.

In this setting, English, French, and Italian courts have dealt with the liability of banking regulators for lack of supervision of banks. Moreover, there has been parallel litigation before the English and French courts concerning liability of the respective regulators for the failure of the Bank of Credit and Commerce International ('BCCI').

In this article it is argued that the expansion of tort liability for misfeasance in public office in the House of Lords' recent decisions in Three Rivers District Council v Bank of England ${ }^{1}$ may contribute to resolving possible conflicts with the European Convention of Human Rights. It may also reduce the differences in the protection offered under English law and EU law. Finally, it is argued that when it comes to establishing limiting mechanisms replacing the ones that have been eroded, English law may make good use of French and EU law.

This article is organised in the following way. In Part II, the framework for banking supervision in the United Kingdom is examined, and the requirements for liability under English law are set out. Liability under EU law in the BCCI case is discussed in Part III. Comparative law material is introduced in Part IV, with reference to parallel proceedings and developments in other European jurisdictions. In Part V, some EU law issues are revisited, in particular. In Part VI, in the light of the EU and European discussion, we return to consider the

* Director, British Institute of International and Comparative Law, London; Senior Teaching Fellow, Institute of European and Comparative Law, and Fellow, Harris Manchester College, University of Oxford.

** Fellow in Comparative Law, British Institute of International and Comparative Law, London; Maître de Conférences invité, Université de Paris 1, Sorbonne.

1 Three Rivers District Council and others $v$ Governor and Company of the Bank of England [2000] 2 WLR 1220; Three Rivers District Council and others $v$ Governor and Company of the Bank of England [2001] UKHL 16. 
broader implication of misfeasance in public office and its role in relation to English negligence liability.

\section{ENGLISH LAW: STATUTORY IMMUNITY AND MISFEASANCE}

The case of Three Rivers District Council v Bank of England ${ }^{2}$ arose out of alleged misfeasance by the Bank of England in supervising the Bank of Credit and Commerce International (BCCI). After BCCI went into liquidation depositors brought damages claims which were struck out in the High Court and Court of Appeal. ${ }^{3}$ In the House of Lords, the first hearing was restricted to two questions of law. ${ }^{4}$ The first question concerned the exact ingredients of the tort of misfeasance in public office. The way the relevant elements of this tort were dealt with, in four separate speeches, has not aided the process of clarification. It illustrates the process of development of the law and also the uncertainties left at this stage. The second question was whether the Bank of England was capable of being liable in damages to the claimants for violation of Community law as laid down in the First Banking Directive. ${ }^{5}$ The House of Lords held that the claimants did not have a damages remedy under Community law.

The second hearing before the House of Lords dealt with the question whether it was right to strike out the claimants' action on the basis that there was no reasonable prospect of the claim succeeding at trial. ${ }^{6}$ The strike out application made by the Bank of England was rejected by a majority of the House of Lords. ${ }^{7}$ A crucial factor in their decision was the reliance, of the judge at first instance and the majority in the Court of Appeal, on the findings of the Bingham Report into the supervision of BCCI. ${ }^{8}$ Lord Hope said that Bingham LJ was not in a position to conduct a fair trial of the issues relating to the tort of misfeasance in public office. ${ }^{9} \mathrm{He}$ agreed with the dissenting opinion of Auld LJ in the Court of Appeal that it would not be right to treat the

2 Three Rivers District Council [2000] 2 WLR 1220; Three Rivers District Council [2001] UKHL 16.

${ }^{3}$ At first instance, after initial proceedings concerning various preliminary issues of law, Clarke J acceded to the Bank of England's application to strike out the action (Judgment of 30 July 1997 (unreported)). The Court of Appeal upheld Clarke J's decision in a joint majority judgment of Hirst and Robert Walker LJJ; Auld LJ dissented: Three Rivers DC v Bank of England [1999] EuLR 211.

4 Three Rivers District Council [2000] 2 WLR 1220.

5 First Council Banking Co-ordination Directive of 12 Dec 1977 (77/780/EEC).

${ }^{6}$ Under the transition arrangements guiding the introduction of the Civil Procedure Rules (CPR) in 1999, the question whether the misfeasance claim should be struck out was determined according to the CPR: Three Rivers District Council [2001] UKHL 16, paras 12-13.

7 The Bank of England asked the House of Lords to give summary judgment against the claimants under Rule 24.2 CPR. Lords Steyn, Hope, and Hutton allowed the appeal against the striking out of the claim. Lords Hobhouse and Millett dissented.

${ }^{8}$ Inquiry into the Supervision of the Bank of Credit and Commerce International HC Paper (1992-3), no 198.

${ }_{9}$ Three Rivers District Council [2001] UKHL 16, para 33 and 80. 
Bingham Report as effectively conclusive on the questions that arose in the litigation. ${ }^{10}$ Lord Hutton also agreed. He held it impermissible for the judge and the majority of the Court of Appeal, in deciding at this interlocutory stage whether there was no real prospect of the action succeeding, to be influenced by the findings and conclusions of Bingham LJ. ${ }^{11}$ Disregarding for this reason the conclusions in the Bingham Report, the majority held that it could not be said the claim had no real prospect of succeeding. The claim had to proceed to trial. There are important statements, in particular in Lord Hope's speech, about the elements of misfeasance which both aid the process of clarification and the development of the tort.

The main features of the UK model of banking supervision are briefly set out below. It is followed by an outline of the law on tort liability applying to the Bank of England as banking supervisor. The scene is then set for the discussion of the Three Rivers case.

\section{A. The Reluctant and Immune Supervisor}

The UK model of banking supervision remained a minimalist one under the responsibility of the Bank of England. Until the adoption of the Banking Act 1979 supervision was implemented on an informal basis ${ }^{12}$ with no comprehensive legislative backing. ${ }^{13}$ The Banking Act 1979 created a statutory system for authorisation of all deposit-taking institutions. This was modernised by the Banking Act 1987 which increased the Bank of England's power to regulate, vet controlling shareholders, and require information. ${ }^{14}$ In 1988 the Bank published a Statement of Principles. ${ }^{15}$ The Statement lays down in some detail the grounds for using the powers to revoke and restrict an authorisation under the 1987 Act.

The protection of depositors was set out, in the long title of the 1979 and 1987 Acts, as the prime objective of banking supervision. In contradiction to this, the focus of a new ideology of banking supervision, prudential supervision, became the solidity of financial institutions and payments systems. Supervision should prevent contagion and systemic risk that could threaten the

10 Ibid, para 33 and 86.

11 Ibid, para 132.

12 Banking supervision was not without bureaucracy: there were many administrative permits and dispensations which had to be obtained if a full range of banking activities were to be attained. This served more as a barrier to entry than a basis for real supervision. 'The underlying idea was to await the development of a new financial institution and then make a judgement', W Möschel, 'Public Law of Banking' (1991) Int Enc Comp Law, vol IX, ch III, at para 20.

13 The Bank never formally invoked the power of recommendation and direction contained in s 4(3) of the Bank of England Act 1946. The Bank's approach to supervision was that of a gentleman's code of ethics and self-regulation. See G Penn, Banking Supervision (London: Butterworths, 1989), 10-11.

14 Ibid, 15.

15 The current Statement of Principles from 1998 was issued by the Financial Services Authority and is complemented by the very extensive Guide to Banking Supervisory Policy. 
stability of the banking system. ${ }^{16}$ The Bank of England developed this over the years, partly in response to criticism over its handling of the different banking crises, ${ }^{17}$ and partly in interaction with international standard setting. In this new perspective, individual bank insolvency could be acceptable. Indeed, under certain circumstances, it might even promote the soundness of the financial system. ${ }^{18}$ This redefinition created a clear tension in relation to the Bank of England's statutory duties, both under domestic and EU law.

The change to modern methods of banking supervision ${ }^{19}$ and the development of formal powers was a long and gradual process. This added another tension: the continued reliance on informal supervision after the establishment of a formal framework with legal duties and sanctions for breach of those duties. In the Bank's practice, omissions to make use of formal sanctions could for instance be justified with market reactions. ${ }^{20}$ The Bank could omit to use sanctions where its 'moral suasion' failed, even though this contrasted with the philosophy of the legislation and the Bank's own Statement of Principles. ${ }^{21}$

The Bank of England Act 1998 followed yet another banking crisis, this time ushering in radical reform. The 1998 Act transferred banking supervision from the Bank of England to the Financial Services Authority, an independent financial services regulator. The Bank of England retained certain functions in relation to the supervision of banks' liquidity.

In terms of potential liability, a statutory immunity from damages liability was introduced under the Banking Act 1987.22 Under the terms of the statute, liability may only arise if the impugned act or omission 'was in bad faith' ${ }^{23}$

16 See the discussion of systemic risk in R Cranston, Principles of Banking Law (Oxford: Oxford University Press, 1997), 71-2.

17 See, for instance, the submissions by the Governor of the Bank of England and its other representatives to parliamentary committees and the annual reports by the Bank on banking supervision.

18 The advantages for a banking supervisor are obvious. Compare systemic risk, which has not yet ever materialised in a systemic collapse, as the only standard of accountability with loss for depositors, which occurs with most individual bank failures.

19 See the discussion of these issues in Cranston, op cit, 91-2.

20 For instance, it could be claimed that that the market would withdraw from a bank whose activity was restricted. This could bring about the collapse of the bank with possible consequences for the stability of the banking market.

21 This is well documented in the Rt Hon Lord Justice Bingham's Inquiry into the Supervision of the Bank of Credit and Commerce International (HC Paper (1992-3), No 198) and in Report of the Board of Banking Supervision Inquiry into Circumstances of the Collapse of Barings (1995). At 260 of the latter Report it was noted that no in situ inspection ('visit') to Barings Bank was ever undertaken before its collapse in 1995.

22 Banking Act 1987, s 1(4). See now Sch 1, s 19(1) of the Financial Services and Markets Act 2000. For an in-depth analysis of UK law, see C Hadjiemmanuil, Banking Regulation and the Bank of England (London: LLP, 1996) and the more general discussion in Cranston, op cit, 91 et seq.

23 This immunity reaches further than restricting mechanisms in other European jurisdictions. It is for instance undisputed that German regulators will be liable in negligence to the banks they supervise. The possible restrictions in German tort liability are in relation to depositors, other creditors and shareholders. 
Regardless of the statutory provisions, regulators have traditionally been well protected by the common law. The cases concerning liability in negligence have been restrictive and not imposed any duty of care upon regulators in respect of economic loss. ${ }^{24}$ The cases concerning the supervision of financial institutions confirm this restrictive approach. ${ }^{25}$ Thus, the statutory immunity may well have been superfluous in 1987. But as the common law develops, and tort liability expands, the immunity may become more important.

The statutory immunity is not applicable to acts taken in bad faith. This exception allowed for claims based on the tort of misfeasance in public office. Misfeasance in public office is the only specifically 'public law' tort in English law. ${ }^{26}$ In the BCCI case the claims against the Bank of England were based on the tort of misfeasance in public office, and the remedies under Community law.

\section{B. Misfeasance in Public Office: The Mental Requirements}

The essence of misfeasance is the exercise of power by a public officer in bad faith that causes loss to the claimant. ${ }^{27}$ The crucial element of this tort is the mental requirement, which may be divided into two alternatives. First, the most stringent form of this tort is known as targeted malice. It requires proof that a public officer has acted with the intention of injuring the claimant. ${ }^{28}$ The second form, untargeted malice, is made out when a public officer acts in the knowledge that he exceeds his powers, and that this act would probably injure the claimant. ${ }^{29}$

The focus of the litigation before the House of Lords in the Three Rivers case was upon the second less stringent form, untargeted malice. In the House of Lords, the debate over the mental element in misfeasance concerned two separate questions. The first question is the public officer's knowledge of the unlawfulness of his or her act. Must it be shown that the defendant knew or suspected that the act was unlawful? Or is it sufficient to show that he ought to have known that such was the case? Which of these differing standards is applicable?

${ }^{24}$ See, eg, Lam v Brennan [1997] PIQR P488 (planning control); Reeman v Department of Transport [1997] 2 Lloyd's Rep 648 (health and safety regulation). See discussion in H McLean, 'Negligent Regulatory Authorities and the Duty of Care' [1988] OJLS 442; PP Craig and D Fairgrieve, 'Barrett, Negligence and Discretionary Powers' [1999] Public Law 626 and 646.

${ }_{25}$ Yuen Kun Yeu v Attorney General of Hong Kong [1988] AC 175; Davis v Radcliffe [1990] 2 All ER 536.

26 See Bourgoin SA v MAFF [1986] QB 716, 776. See also Dunlop v Woollahra Municipal Council [1982] AC 158, 172; Jones v Swansea CC [1990] 3 All ER 737.

27 Generally, see Craig, Administrative Law, 4th edn (London: Sweet \& Maxwell, 1999), 875-80; S Arrowsmith, Civil Liability and Public Authorities (Winteringham: Earlsgate, 1992), 226 ff; W Wade, Administrative Law, 8th edn (Oxford: Oxford University Press, 2000), 765 ff; McBride, 'Damages as a Remedy for Unlawful Administrative Action' [1979] CLJ 323.

${ }_{28}$ Bourgoin SA v MAFF [1986] QB 716,776. See also Dunlop $v$ Woollahra Municipal Council [1982] AC 158, 172.

${ }_{29}$ Three Rivers District Council [2000] 2 WLR 1220 and [2001] UKHL 16. 
The second question concerns the awareness of the consequences of that unlawful act. What is the requisite state of mind of the public officer concerning the likelihood of the claimant being damaged by the unlawful act? The manner in which the courts frame these elements is an essential part of understanding the role of the tort in controlling public wrongdoing. The mental element of the tort is its main control-mechanism.

The first judgment of the House of Lords in Three Rivers resolved these questions in the following way. On the knowledge of illegality, it was held that the claimant must show either that the officer had actual knowledge that the impugned act was unlawful or that the public officer acted with a state of mind of reckless indifference to the illegality. ${ }^{30}$ On the awareness of consequences, counsel for the claimants had argued that that there was no need for it to be shown that the public officer had actually known that his actions would probably injure the claimants, arguing that recovery should be made for all reasonably foreseeable loss. ${ }^{31}$ This had been supported by Lord Justice Auld's dissenting judgment in the Court of Appeal. ${ }^{32}$ In the first judgment of the House of Lords, the test of reasonable foreseeability was rejected. The relevant test was subjective. It was necessary to show that the public officer knew that his act would probably injure the claimant. As with the knowledge as to the unlawfulness of the act, it would seem that reckless indifference as to the consequences, in the sense that the officer acted without caring whether the consequences happened or not, was sufficient.

The second judgment of the House of Lords applied the test to rule on the question whether the claim should be summarily dismissed. The House of Lords stated that the correct test for misfeasance was that laid down in the first judgment. ${ }^{33}$ But the second judgment did more than illustrate the practical application of the requirements of the tort. The second judgment provided important clarification of two aspects of the action, the necessary knowledge as to consequences in terms of untargeted malice, and the exact meaning and role of bad faith.

\section{Knowledge as to Consequences}

The formulation of the requirement to show knowledge as to consequences will be a crucial point when the case goes to trial. The exact articulation of these consequences cover disputed territory but essentially entail the knowledge or recklessness of the failure of BCCI, the lack of a rescue package to save it, and the resultant loss of the depositors' money.

\footnotetext{
30 Ibid. See also [2001] UKHL 16 , para 121 (Lord Hutton)

31 See argument in the Court of Appeal: Three Rivers DC v Bank of England [1999] EuLR 211, 243.

32 Three Rivers District Council [1999] EuLR 211, 270-2, 370 (CA).

33 Three Rivers District Council [2001] UKHL 16, para 41.
} 
In the second judgment of the House of Lords in Three Rivers, ${ }^{34}$ it was reiterated that what is required is recklessness in a subjective sense of awareness of risk by the defendant. ${ }^{35}$ Inadvertent recklessness, in the sense of reasonable foreseeability, was not enough. But it was again repeated at various stages that the test as to knowledge of the consequences covers reckless indifference to the risk of loss, ${ }^{36}$ which extends to 'recklessness about the consequences, in the sense of not caring whether the consequences happen or not, will satisfy the test. ${ }^{37}$

The 'couldn't care less' test for recklessness as to consequences is elastic. On one interpretation, it could imply advertence to the risk of the consequences occurring but accompanied by entire indifference to whether that happened or not. This combines awareness with a lack of concern. Another interpretation is more radical, and would cover the circumstances where the defendant had not thought about the particular consequence of certain acts or omission and thus showed a practical indifference to their occurrence. This has sometimes been used in criminal law cases of alleged rape where the defendant has been convicted on the basis that he 'couldn't care less' whether the victim was giving consent or not. ${ }^{38}$ There are those who believe that it hard to reconcile such an approach with the label of advertent or subjective recklessness. ${ }^{39}$

Could there be grounds for arguing in favour of the broader interpretation in the context of misfeasance in public office? There are some indications in Lord Hope's decision of a recognition of the inherent problems in taking too narrow a view of foresight of consequences. This is highlighted in two particular features of his judgment. First, counsel for the Bank had argued that the claim should be struck out on the basis that the statement of claim did not support an allegation of 'knowledge, belief or suspicion of likely or probable loss.' Lord Hope refused to strike out the claim on this basis, and emphasised the importance of discovering the facts at trial before making specific definitions of the state of mind required. ${ }^{40}$ This suggests that the trial judge will have a certain amount of room to manoeuvre in framing the exact test. Second, a

34 Ibid, 16.

35 Three Rivers District Council [2001] UKHL 16, paras 44, 46, 62, and 76.

${ }^{36}$ See, eg, Three Rivers District Council [2001] UKHL 16, para 58.

37 Three Rivers District Council [2001] UKHL 16, para 62. Another variant of this is referred to in Lord Hobhouse's judgment as 'blind eye knowledge'-see para $164 \mathrm{ff}$.

38 See Satnam and Kewal S (1984) 78 Cr App R 141.

39 A Ashworth, Principles of Criminal Law, 3rd edn (Oxford: Oxford University Press 1999) 186-87; see also 416 about Caldwell recklessness and deception offences: there dishonesty may be shown even when the defendant gave no thought to the obvious risk that a representation was false, Goldman [1997] Crim LR 894.

40 Three Rivers District Council [2001] UKHL 16, para 60. See Ashworth, Principles of Criminal Law 180-81 about the distinction between the required state of mind and the process of drawing inferences about it which is also an issue in Lord Hope's speech. P Cane 'Mens Rea in Tort Law' (2000) 20 OJLS 533, 542-3 takes this discussion further, and is less critical of the judicial process failing to distinguish between the required state of mind and the (factual) inferences than Ashworth. 
later aspect of Lord Hope's judgment is also revelatory about the required state of mind of the public officer. Lord Hope admitted that he saw much force in a section of Auld LJ's dissenting judgment in the Court of Appeal which underlined the iniquity of allowing the defendants to rely upon the reason for their unlawfulness - the failure to fulfil its supervisory obligations properlyto defeat the misfeasance claim on the basis that this very failure-its 'selfimposed ignorance'-precluded them from suspecting that the depositors would probably suffer loss.

Auld LJ's argument strikes right at the heart of requirement of foresight. Does Lord Hope's recognition of the force of Auld LJ's comment imply a more indulgent approach to claimants meaning that subjective awareness of risk might not always be required? Most probably not. Given Lord Hope's basic definition of recklessness for untargeted malice in which he emphasised the awareness of risk, it would seem that the narrower interpretation of the 'couldn't care less test' is right: it has to be shown 'that the public officer was aware of a serious risk of loss due to an act or omission on his part which he knew to be unlawful but chose deliberately to disregard that risk' ${ }^{41}$ But at the very least, the approval of Auld LJ's statement suggests that at trial the judge should draw the necessary inferences from any attempt that is made by the Bank to make use of its self-imposed lack of prescience concerning the effects of its supervisory activities to defeat a claim for lack of foresight of consequences.

A related issue is the degree of awareness of risk that will have to be averred by the claimants. The defendants had argued that there needed to be proof of awareness of probable loss. In response to this, Lord Hope underlined that in the end this question was a matter of fact and degree to be determined by the judge at trial. ${ }^{42}$ In giving guidance for that process his Lordship acknowledged that an important consideration was that supervision was conferred by statute in order to protect depositors. The First Banking Directive was premised upon this policy. Underpinning the supervisory system is the fact that in the absence of proper supervision, deposits are likely to be at risk. In that context, Lord Hope expressed the test to be applied at trial as whether the risk of loss was sufficiently serious to warrant a finding of reckless on the part of the supervisor. ${ }^{43}$

\section{The Role of Bad Faith}

Another important aspect of Lord Hope's judgment is the clarification of the exact meaning and role of bad faith. The first House of Lords' judgment had

41 Three Rivers District Council [2001] UKHL 16, para 46.

42 Ibid, para 60.

${ }^{43}$ Ibid, paras 60 and 76 . He also expressed this in terms of the following test: 'the public officer was aware of a serious risk of loss due to an act or omission on his part which he knew to be unlawful but chose deliberately to disregard that risk' (para 46). 
left this question somewhat open. Counsel for the Bank of England argued that the action should be struck out because the pleadings did not make specific allegations of dishonesty in the sense of subjective bad faith on the part of officials of the bank. ${ }^{44}$ Lord Hope flatly rejected this argument. ${ }^{45}$ In effect he held that proof of the elements of the tort in terms of knowledge of unlawfulness of the act or omission and its consequences was enough. ${ }^{46}$ This is particularly important in terms of recklessness as to the consequences. It would seem that proof that the defendant did not care whether the consequences happened or not is enough. Bad faith is demonstrated by recklessness on the part of the administrator in disregarding the risk. ${ }^{47}$ Lord Hope emphasised that no additional element of dishonesty or bad faith was required. ${ }^{48}$

This is a significant point in favour of the claimants in the Three Rivers case. It would probably have been difficult to show outright bad faith, over and beyond the unlawfulness and consequences elements, on the part of the officials in dealing with BCCI. Now, according to the majority judgment of their Lordships this is no longer necessary. This clarification of the role of bad faith is also significant in a wider sense. It is sufficient to show disregard of a sufficiently serious risk of loss, coupled with unlawfulness. This clarifies and broadens the interpretation of bad faith. It will serve to make the tort of misfeasance more broadly applicable for compensating administrative wrongs. ${ }^{49}$ Reckless administrators are a more common phenomenon than outright dishonest ones.

We will examine the ramifications of the re-shaping of the tort of misfeasance in a later section. We turn now to examine the House of Lords decisions in respect of Community Law.

\section{THE EU LAW ISSUES BEFORE THE ENGLISH COURTS}

\section{A. EU Law in the UK Courts: The General Issues}

Banking supervision in the UK was for a long while fundamentally different from other EU member states. Even after many years of EU harmonisation, UK banking supervision remained minimalist, with the Bank of England as a reluctant supervisor. As we have seen, banking supervision was first put on a statutory footing in the Banking Act 1979. The 1979 Act $^{50}$ transposed into English Law the newly adopted EU First Banking Directive. ${ }^{51}$ It was after the secondary banking crisis of the early 1970s that the Bank of England had to

\footnotetext{
44 Ibid, paras 57 and 62.

47 Ibid, para 44.

45 Ibid, para 62.

46 Ibid, paras 44 and 62.

48 Ibid, para 62.

49 For a restrictive interpretation of the bad faith requirement in the Court of Appeal, see Greville $v$ Sprake [2001] EWCA Civ 234; Thomas v Chief Constable of Cleveland [2001] EWCA Civ 1552.

50 See the useful overview of the regulatory system in Three Rivers District Council [2000] 2 WLR 15 (abridged) [1999] EuLR 211 (in full) CA.

51 In particular, the First Banking Directive of 1977: First Council Banking Co-ordination Directive of 12 Dec 1997 (77/780/EEC).
} 
accept some degree of formalisation of banking supervision in EU legislation. The UK had blocked the First Banking Directive but the objections to the proposal were then withdrawn. ${ }^{52}$

In the BCCI case, the different standards of banking supervision in the UK compared with those applicable in other European countries could potentially have been an issue both in the context of the misfeasance claim and the claim for breach of EU law. The tension between the requirements of the First Banking Directive and UK banking supervision could only have been appreciated fully with this in mind. But this tension never became an issue in the proceedings or in the judgments.

Liability under EU law was evidently attractive to the claimants, as it would have avoided many of the restrictive mental elements required in misfeasance. In the event, all three courts confirmed that misfeasance in public office is a narrower tort than that based on a sufficiently serious breach of Community law. There was extensive discussion of the Community law issues. Only the dissenting judge in the Court of Appeal, Lord Justice Auld, held that a claim could be based on Community law. He held that EU legislation did impose duties on the Bank of England. The purpose was to protect depositors. The obligations imposed upon the Bank by the EU legislation could give depositors a right of redress against it for breach of those obligations.

In the House of Lords, Lord Hope of Craighead gave the main speech on Community law issues. ${ }^{53} \mathrm{He}$ relied on Lord Justice Auld for the formulation of the two critical questions. ${ }^{54}$ First, did the First Banking Directive entail the grant of rights to individual depositors and potential depositors? Secondly, was the content of those rights identifiable on the basis of the provisions of the Directive?

Lord Hope reviewed the European Court's case law on the First Banking Directive and he found little support there. He relied on an examination of the terms of the Directive itself. He pointed out that the recitals showed that it was intended to be the first step in a continuing process to coordinate the supervision of credit institutions. He concluded that the protection of savings was merely a matter to which regard had to be had, along with the creation of equal conditions of competition, in the process of coordination.

Lord Hope further held that the only duty that the First Banking Directive imposed was a duty to cooperate. When the Directive allowed the withdrawal of authorisation in limited circumstances, its terms were restrictive rather than obligatory: it could not place a duty to act on the Bank of England. Various issues arising from this judgment merit examination in greater depth.

\section{B. The Purpose of the Directive and the Duties on the Supervisor}

The BCCI failure was the very type of failure that the First Banking Directive

52 See Cranston, op cit, 70.

53 [2000] 2 WLR 1220, 1236.

54 Ibid, 1242. 
was intended to prevent. BCCI operated in several member states at a stage when the coordination of banking supervision was being developed at a Community level. It is well documented that BCCI was allowed to continue its business for a long period due to coordination problems between the banking supervisors in different member states.

The First Banking Directive was intended to secure non-discriminatory treatment of banks from other member states. This was effected by removing certain forms of direct discrimination against foreign banks or initiating procedures, and by introducing the right to judicial review, for instance in the authorisation of banks. The opening up of the banking markets in the Directive was accompanied by certain safeguards to protect the interest of depositors. Depositors were to be protected by certain supervisory measures that should be undertaken by national authorities. In particular they were to protect depositors from the problems of coordination between different national banking supervisors.

This was the first step in establishing a new supervisory system in the Community. It is hard to accept the position taken in the judgment by the House of Lords that the Bank of England could not have a duty to make use of the powers to revoke an authorisation. It is hard to do so on the basis of a literal interpretation. On the basis of the background for, and context of, the Community regulation of banking supervision it is even more difficult. The provisions of the Directive must also be read in light of the supervisory systems of the other member states that in effect were adopted as the Community model with these particularly fundamental consequences in the UK. ${ }^{55}$

Lord Justice Auld in the minority in the Court of Appeal interpreted the provisions of the Directive on supervisory duties in a way that is wholly consistent with this context. He also made use of the case law of the Court of Justice on the Directive, including the ruling in the Parodi case. ${ }^{56}$ The other judges attempted to explain away these cases, one by one, ${ }^{57}$ with brief and mostly formal arguments.

55 See the discussion of the supervisory systems of other member states by M Andenas and D Fairgrieve, 'To Supervise or to Compensate', in Andenas and Fairgrieve, Judicial Review in International Perspective (London: Kluwer Law International, 2000).

56 Societe Civile Immobiliere Parodi v Banque H. Albert de Bary et Cie (Case C-222/95) [1997] ECR I-3899; [1997] All ER (EC) 946, ECJ. Another interesting point concerns the French courts' application of the ECJ's preliminary ruling which arguably is inconsistent with that of the House of Lords. That should have resulted in a new reference to the ECJ by the House of Lords. See the Editorial in [2000] Euredia 305 signed by the Editorial Board under the title 'European Banking Law as Applied by the House of Lords: Overshadowing the Acte Clair Doctrine', and also the case note in [2000] Euredia 379.

57 In Dillenkofer [1996] ECR I-4845 para 22 the condition that the directive conferred rights on individuals was formulated in the following way: the result prescribed by the directive must entail the grant of rights to individuals and the content of those rights must be identifiable on the basis of the directive. This formulation does not allow a national court to disregard the European Court's case law on the interpretation of a directive! 


\section{Damages and Direct Effect}

The discussion of liability was in all three instances, from Mr Justice Clarke to the House of Lords, closely linked to the requirements for direct effect. As mentioned, Lord Hope in the House of Lords let liability depend on two uncontroversial questions. ${ }^{58}$ First, did the First Banking Directive entail the grant of rights to individual depositors and potential depositors? Secondly, was the content of those rights identifiable on the basis of the provisions of the Directive? But there are several places in Lord Hope's speech, as it is in the majority judgments of the lower courts, where it seems as if the requirements for tort liability include precision and unconditionality, which of course are the basic requirements for direct effect. ${ }^{59}$

The condition for tort liability that the directive conferred rights on individuals ${ }^{60}$ does not go that far. The condition is that the result prescribed by the directive must entail the grant of rights to individuals, and that the content of those rights must be identifiable on the basis of the directive. This is different from the precision and unconditionality required for direct effect.

In the majority decisions of the English courts in the Three Rivers litigation the requirement of the granting of rights to individuals has become materially different from what is required according to the authoritative case law of the European Court.

It could be noted here that the German Government proposed, under the negotiations on the First Banking Directive, the inclusion of a clause stating that the Directive did not give rise to liability in damages to depositors for the national regulator. The European Commission opposed this limitation of liability. The Commission's view was that it would be inappropriate to limit in the directive the remedies provided in national law. Damages liability for breach of Community law (as a matter of Community law) has of course been established later. ${ }^{61}$ The choice was made not to limit a possible liability based on the requirements of the Directive. ${ }^{62}$

\section{PARALLEL PROCEEDINGS AND DEVELOPMENTS IN OTHER EUROPEAN JURISDICTIONS}

\section{A. Proceedings in France}

The English legal system is by no means the only system to have considered the question of the liability of regulatory authorities. The French administra-

58 [2000] 2 WLR 1220, 1242.

59 Directly effective EU law can be relied on in national courts. Member States can be held liable in tort for breach of EU law whether the provisions of EU Law are directly effective or not.

60 This condition, established in the European Court's judgment in Dillenkofer [1996] ECR I4845 para 22, was referred to in the judgments as 'the Dillenkofer condition'.

61 See Part V below.

62 This was not brought to the attention of the English courts in the Three Rivers litigation. 
tive courts have also been grappling with similar issues, and the case law has been developing swiftly.

Due to the complex and sensitive nature of bank supervision, the French Conseil d'Etat traditionally required claimants to show faute lourde, or grave fault, in state liability actions concerning the activities of the main agency responsible for banking supervision, the Commission Bancaire. ${ }^{63}$ The standard of liability applied by the courts was particularly high, ${ }^{64}$ and only one claim had ever satisfied this faute lourde requirement. ${ }^{65}$

This restrictive approach has however recently been challenged by claimants in a series of cases. In the case of Kechichian, depositors brought an action against the state alleging that the Commission Bancaire had failed to supervise properly a bank, the United Banking Corporation, contributing to its failure and the consequent loss of their deposits. At first instance, the claims were rejected. On appeal, the Cour Administrative d'Appel de Paris reiterated the principles enunciated in an earlier decision concerning the Bank of Credit and Commerce International, ${ }^{66}$ in which it had abandoned the traditional prerequisite of faute lourde and decided that the standard of faute simple applied to the supervisory role of the Commission Bancaire. ${ }^{67}$ The Cour Administrative d'Appel thus continued the seemingly inexorable shift from graded fault standards in French administrative law ${ }^{68}$ towards a unified standard of faute simple. ${ }^{69}$

An appeal was made to the Conseil d'Etat. The case was assigned to the Assemblée du Contentieux, the Plenary Chamber of the Conseil d'Etat denoting the importance of the issues raised by the claims. In an extremely significant judgment, the Conseil d'Etat overturned the Cour Administrative d'Appel's decision on the standard of fault. ${ }^{70}$ The claimants needed to show that the Commission Bancaire had committed a faute lourde in its supervisory activities.

63 Conseil d'Etat, 29 Dec 1978, Darmont [1978] Recueil des Décisions du Conseil d'Etat, 542. Other agencies also exercised supervisory functions: see further D Fairgrieve and K Belloir 'Liability of the French State for Negligent Supervision of Banks' (1999) 10 European Business Law Review, 17.

${ }^{64}$ Cliquennois, 'Essai Sur La Responsabilité de l'Etat du Fait de Ses Activités de Contrôle et de Tutelle' [1995] Les Petites Affiches, no 98, 4.

65 This case is itself over 35 years old and relates to facts that took place in the 1950s. Conseil d'Etat 24 Jan 1964, Achard [1964] Recueil des Décisions du Conseil d'Etat, 43.

66 Cour Administrative d'Appel de Paris, 30 Mar 1999, El Shikh, AJDA.1999.951. See discussion in Andenas and Fairgrieve, 'To Supervise or to Compensate? A Comparative Study of State Liability for Negligent Banking Supervision' in Andenas and Fairgrieve, Judicial Review in International Perspective (London: Kluwer Law International, 2000), 348 et seq.

67 Cour Administrative d'Appel de Paris, 25 Jan 2000, Kechichian, Req 93PA01250.

68 See Errera [1990] Public Law 571; Raynaud and Fombeur, AJDA 1998, 418, 424.

69 See Conseil d'Etat 20 June 1997, Theux, Recueil des Décisions du Conseil d'Etat, $253 \mathrm{concl}$ Stahl (emergency services); Conseil d'Etat 29 Apr 1998, Commune de Hannappes, Recueil des Décisions du Conseil d'Etat, 185, RDP 1998.1001 note X. Prétot, JCP 1999.II.10109 note Genovèse (fire-services).

${ }^{70}$ Conseil d'Etat, 30 Nov 2001, Kechichian, AJDA 2002.136. See extended discussion in D Fairgrieve, State Liability in Tort: A Comparative Law Study (Oxford: Oxford University Press, forthcoming). 
Nonetheless, the Conseil d'Etat upheld the lower Cour Administrative d'Appel's finding of liability. The Commission Bancaire's failure to act decisively to ensure that the bank was re-capitalised within a short space of time, ${ }^{71}$ and its willingness to backtrack on initial requirements amounted to a faute lourde. For only the second time in its history, the state was found liable in damages by the administrative courts for the loss caused to investors by the collapse of a credit institution. However, the state was not found liable for the full loss of these depositors. As the primary causal contributor of the bank's failure was the fraudulent activities of its directors, the Conseil d'Etat held the state solely liable for the part it played in the failure of the bank, which was held to represent 10 per cent of the lost deposits.

Various conclusions can be drawn from this case. The Conseil d'Etat decided that in this sensitive area of governmental activity the time was not right for a shift from faute lourde to faute simple. The protective role of faute lourde was still deemed necessary in order to provide a 'margin of manoeuvre' for the public body. ${ }^{72}$ But it would be wrong to view this case as a simple re-statement of the previous case law. Indeed, it is possible to perceive it as a significant step forward. The traditional approach to claims in this area was very restrictive and the standard of liability very high. ${ }^{73}$ It would not be exaggerated to say that a form of quasi-immunity applied. ${ }^{74}$ The approach of the Conseil d'Etat in the most recent case strikes a different note. Faute lourde was maintained but the judges sent a signal that they are prepared to look closely at the regulator's activities and will impose liability if the appropriate standards are not met. The shift is illustrated by the difference in approach between the Tribunal Administratif and the Conseil d'Etat. Both applied the standard of faute lourde but only the latter found that it had been made out. ${ }^{75}$

The French case law also affords an opportunity to reflect upon the control mechanisms. The means of controlling the existence and extent of liability are by no means limited to the notion of fault. The French cases show that various other mechanisms exist. In the case of $E l$ Shikh, concerning the BCCI failure, depositors complained that the French regulators had been at fault in the way they supervised BCCI. It was alleged inter alia ${ }^{76}$ that the BCCI's banking

71 Subsequent to the issuing of a formal 'lettre de suite', which had been motivated by an inspection which had uncovered weaknesses in the bank's finances.

72 Chapus, Droit Administratif Général, vol 1, 13th edn (Paris: Montchrestien, 1999), para 1463.

73 Cliquennois, 'Essai Sur La Responsabilité de l'Etat du Fait de Ses Activités de Contrôle et de Tutelle' [1995] Les Petites Affiches, no 98, 4.

74 Only one claim had previously satisfied the traditional faute lourde requirement. This case is itself over 35 years old and relates to facts that took place in the 1950s: Conseil d'Etat, 24 Jan 1964, Achard [1964] Recueil des Décisions du Conseil d'Etat, 43. For discussion of this, see generally Fairgrieve and Belloir (1999) 10 European Business Law Review, 13.

75 Tribunal Administratif de Paris, 7 July 1993 (unreported).

76 Cour Administrative d'Appel de Paris, 30 Mar 1999, El Shikh, AJDA.1999.951. For a fuller examination of the facts of the case, see Andenas and Fairgrieve, 'To Supervise or to Compensate?', op cit. 
licence should have been withdrawn, and that the primary supervisory body, the Commission Bancaire, had failed to act promptly and in an appropriate manner to irregularities it had discovered during investigations at the Bank. The Cour Administrative d'Appel's decision to apply faute simple in this case must now be viewed as erroneous. Nonetheless, the case is still instructive in other respects. Despite the shift in the standard of fault, the claim against the French state by the BCCI depositors failed. Indeed, the court did not even decide whether or not the Commission Bancaire's actions constituted a faute simple.$^{77}$ It instead rejected the claims on the basis that the causal link between the alleged faults and the claimants' loss was not established. ${ }^{78}$ The Bank's collapse was primarily due to fraudulent activities of its employees at the BCCI group level, and particularly at the Bank's principal place of business in London. There was no direct causal link between the allegedly deficient supervision of the French branches of BCCI for which the French supervisory authorities were responsible, and the claimants' loss.

The Conseil d'Etat's recent decision in Kechichian also illustrates that creative solutions at the level of causation can allay fears of, in common law terminology, the opening of a floodgates of claims. The Conseil d'Etat reduced the liability of the State in line with the part it played in the failure of the bank, which represented 10 per cent of the ultimate loss. Moreover, the lower court's solution-though it proved unattractive to the Conseil d'Etatmight be of interest from a comparative law perspective. In Kechichian, the Cour Administrative d'Appel found that the inadequate supervision of the bank had played a causally significant role in its failure. But it considered that that had only deprived the investors of a chance of avoiding the bank's collapse. So, the damages award was assessed as 20 per cent of the losses of each depositor.

\section{B. Parallel Issues in German and Italian Law: Are Depositors Protected?}

In traditional German doctrine, ${ }^{79}$ supervision of financial institutions was undertaken in the interest of the public at large and not to protect individuals. ${ }^{80}$ Consequently, individual depositors could not have any tort claim against the banking regulator. This doctrine was premised upon a decision by the

77 In respect of the parallel claim concerning the exercise of the Commission Bancaire's disciplinary power, the French courts maintained the pre-requisite of faute lourde laid down in the case of Darmont in 1978 (n 63 above). The Court held that on the facts of the case the Commission Bancaire did not commit a faute lourde.

${ }^{78}$ For a more detailed examination of this point, see Andenas and Fairgrieve, 'To Supervise or to Compensate?', op cit.

${ }_{79}$ F Ossenbühl, Staatshaftungsrecht (Munich: Beck, 1998), 64.

80 German law is of interest here as a background to the First Banking Directive. It is also necessary to understand a point based on the legislative history of the directive concerning a proposed article in the Directive limiting liability to depositors (see under Part III above). 
Bundesgerichtshof (Supreme Court) in a case concerning the supervision of insurance companies. ${ }^{81}$ But in two decisions from 1979, Wetterstein $^{82}$ and Herstatt, ${ }^{83}$ the Supreme Court departed from this doctrine. The Court recognised that individual bank creditors (Gläubiger), and this included depositors, represented a protected interest. ${ }^{84}$ Banking supervision was undertaken not only in the general interest but also in the interest of individuals. In response to these cases, new legislation was introduced in 1984, stating expressly that banking supervision is undertaken in the public interest only. This was intended to exclude claims from individuals. A statutory immunity directly barring tort claims would be unconstitutional as Article 34 of the German Constitution prohibit such immunities. ${ }^{85}$ The only way open to the legislator was to limit the purpose of banking supervision.

It is no surprise that the new legislation has been criticised by commentators as both unconstitutional and contrary to EU law. ${ }^{86}$ If the 1984 legislation is primarily a limitation of liability, it cannot be constitutional. The question may be more doubtful if the 1984 legislation is considered to be a real limitation of the primary functions and purpose of banking supervision. The limitation of liability that was intended by the 1984 legislation will not affect those who are directly affected by an unlawful administrative act of the Bundesaufsichtsamt such as banks or their management. Here the ordinary liability rules apply. 87

There is also interesting litigation before the Italian courts. In Italy, depositors have an unusual constitutional protection. Article 47 of the Italian Constitution (1948) provides that the state shall encourage and supervise saving in all its forms. This article was adopted to impose a duty on the state to supervise banks in the interest of depositors. It influenced the language of the Treaty of Rome, which in Article 57(2) required unanimity for the adoption of Community measures concerning the protection of savings. But it is

81 BGH Z 58, 96 at 98.

82 BGHZ 74, 144 at 147.

83 BGHZ 75, 120 at 122 . In the Herstatt case the claimants were a group of private depositors. The Gemeinschaftsfonds bzw. Feuerwehrfonds proved insufficient at the insolvency of the Herstatt-Bank in 1974. The response was the establishment in 1976 of the Einlagesicherungsfonds des Bundesverbands der deutschen Banken, as an industry initiative to pre-empt legislation establishing a public deposit guarantee scheme. See further H Schimansky, H-J Bunte, and H-J Lwowski, Bankrechts-Handbuch, vol 1 (Munich: Beck, 1997), para. 25 at 3, 25.

84 Ossenbühl, op cit, 63-4.

85 It is interesting to note that Art 34 GG also bars legislation that qualifies the degree of fault required for liability. French distinctions such as faute lourde could not be expected to pass review under Art 34 GG. The Constitution does not, on the other hand, bar a limitation of the right of recourse against the civil servant personally to a qualified form of negligence.

86 See also the discussion by WR Schenke and J Ruthig 'Amtshaftungsansprüche von Bankkunden bei der Verletzung staatlicher Bankenaufsichtsplichten', NJW (1994), 2324; and Ossenbühl op cit, 64 with extensive references.

87 V Szagunn, U Haug, and W Ergenzinger, 6th edn, Gesetz über das Kreditwesen (Stuttgart: Verlag W Kohlhammer 1997), 170. The parallel UK immunity excludes also this kind of liability; this was indeed the main purpose of the immunity. 
only in a series of recent judgments that the way has been paved for tort remedies against banking supervisors.

The Italian Corte di Cassazione (Supreme Court) decided in two judgments that the Banca d'Italia in principle can be held liable in damages to investors and depositors for negligent supervision of banks. ${ }^{88}$ More recently, the Corte di Cassazione has applied the newly established damages liability to protect legitimate interests and held the securities commission Consob liable for investors' losses. ${ }^{89}$ The principles enunciated in this decision might be extended to the sphere of banking supervision. ${ }^{90}$ Accordingly, the supervisory authority must act in accordance with general principles of fairness and good administration, and must use its powers whenever necessary in order to protect interests safeguarded by law. In the Consob case, the Corte di Cassazione, overturning old jurisprudence, extended the tort remedies available to depositors and investors.

\section{TORT LIABILITY UNDER EUROPEAN COMMUNITY LAW}

The impact of European Community law, even if it did not give rise to a damages claim in this case, is of importance. In Brasserie du Pecheur and Factortame ${ }^{91}$ the European Court of Justice clarified the conditions for liability: 'Community law confers a right to reparation where three conditions are met: the rule of law infringed must be intended to confer rights on individuals; the breach must be sufficiently serious; and there must be a direct causal link between the breach of the obligation resting on the State and the damage sustained by the injured parties. ${ }^{92}$

The notion of a 'sufficiently serious breach' was thus introduced by the

88 Although the Corte di Cassazione did not actually decide on the issue of liability. After the Supreme Court's ruling in Cass 22 July 1993, n. 8181 in the case following the liquidation of the Banca Popolare di Fabrizia, the Tribunale di Roma, on the facts of the case, did not find in favour of the claimant. The Supreme Court held again in Cassa di Risparmio di Prato-Landini (Cass 27 October 1994, n. 8836) that the Banca d'Italia could be liable in damages to investors for lack of supervision and that such claims fall within the competence of the civil courts. According to Article 2043 of the Italian civil code, which also applies to the public bodies, 'any wilful or negligent act that causes an unjustified damage to another obliges the person who has committed the act to pay damages'. This covered only the infringement of someone's 'rights' and not their 'legitimate interests'. A depositor would only have a legitimate interest in the supervision of the bank and not a right. In Cassa di Risparmio di Prato-Landini the possibility is opened up for granting depositors rights in this sense, making a damages remedy available. Focus shifted to the right of the integrity of their assets from the legitimate interest in the lawful use of supervisory powers.

89 Cass Sez I, 3 Mar 2001, n. 3132. The new doctrine on tort liability for breach of legitimate interests generally was established in the case reported as Cass SSUU, 22 July 1999, n. 500. A damages remedy became available without having to reclassify the 'legitimate interests' as rights.

90 See excellent discussion of this case, by Roberto Caranta, 'Public Law Illegality and Governmental Liability' in D Fairgrieve, M Andenas, and J Bell (eds), Tort Liability of Public Authorities in Comparative Perspective (London: BIICL, 2002).

${ }_{91}$ In Brasserie du Pecheur SA $v$ Federal Republic of Germany; $R v$ Secretary of State for Transport, ex p. Factortame Ltd (No 4) [1996] ECR I-1029.

92 At para 51. 
$\mathrm{ECJ}$ as the core condition of liability. In a second generation of cases, ${ }^{93}$ the ECJ has developed and refined the remedy, concentrating on elaborating the condition of causation. ${ }^{94}$

In Three Rivers, the House of Lords held that there was no Community right for depositors to be breached. There was no need to deal with issues of causation. Causation, as with the other conditions of liability for breach of Community law, is determined in the first place by Community law. National rules of causation that do not provide an effective standard of protection will be discarded. However, also outside the formal reach of Community law these causation rules may be of assistance. In the context of expanding liability as a matter of English law, one issue is the guidance that can be found in Community law, as in the French case law, on causation as a limiting mechanism. One starting point may be the rather stringent principles governing the liability of Community institutions, ${ }^{95}$ the other the evolving causation rules for Members States' breach of Community law

Neither did the House of Lords have to revisit the test of 'sufficiently serious breach'. When Lord Hope uses 'sufficiently serious risk', this is at an evidentiary level. ${ }^{96}$ However, the way in which this is done does bring misfeasance liability under English law closer to the level of protection offered by liability under Community law.

\section{THREE RIVERS: THE BROADER PERSPECTIVE}

The decision in Three Rivers should be placed in the context of general developments of tort law. Domestic tort remedies have been developing under the influence of European Human Rights Law and European Community Law, ${ }^{97}$

93 See Case C-424/97, Salomone Haim v Kassenzahnärztliche Vereinigung Nordrhein, judgment of 4 July 2000; Case C-140/97, Rechberger and Greindl v Austria [1999] ECR I-3499; Case C-321/97, Ulla-Brith Andersson and Susanne Wåkerås-Andersson v Swedish State [1999] ECR I3551; Case C-302/97, Konle v Republic of Austria [1999] ECR I-3099; Case C-319/96, Brinkmann Tabakfabriken GmbH v Skatteministeriet [1998] ECR I-5255; Case C-127/95, Norbrook Laboratories Limited v Ministry of Agriculture [1998] ECR I-1531.

94 See Tridimas, 'Liability for Breach of Community Law: Growing up and Mellowing Down?', in D Fairgrieve, M Andenas, and J Bell (eds), Tort Liability of Public Authorities in Comparative Perspective (London: BIICL, 2002).

95 However, so far no apparent attempt has been made by the Court to borrow, in developing causation rules for Member States' liability for breach of Community law, from its case law on Art 228(2) and liability for Community institutions with regard to causation, see the criticism by W Van Gerven, 'Taking Article 215(2) EC Seriously', in Beatson and Tridimas (eds), New Directions in European Public Law (Oxford: Hart Publishing, 1998), 35-48.

${ }_{96}$ Three Rivers District Council [2001] UKHL 16, para 60. The distinction between the substantive test and the evidentiary matters is an unclear one, also in the practice of the English appellate courts, see A Ashworth, Principles of Criminal Law, 180-1 and P Cane 'Mens Rea in Tort Law' 542-3 (n 40, above).

97 J Wright, Tort Law and Human Rights (Oxford: Hart Publishing, 2001); B Markesinis, J-B Auby, D Coester-Waltjen, and S Deakin, Tortious Liability of Statutory Bodies: A Comparative and Economic Analysis of Five English Cases (Oxford: Hart Publishing, 1999); Amos, 'Extending the Liability of the State in Damages' [2001] LS 1; PP Craig and D Fairgrieve, 'Barrett, Negligence and Discretionary Powers' [1999] Public Law 626. 
and the Three Rivers decision may be seen as part of this process. Comparative Law may also be of assistance in this gradual development. The broadening of the elements of misfeasance in public office may make this tort more attractive to claimants.

\section{A. The European Context}

We have already analysed the rejection of the Community law damages claim in Three Rivers. Despite this position, and the questionable way in which the European cases were interpreted and the preliminary reference avoided, the European law influence on the development of the English law tort of misfeasance in the Three Rivers case should by no means be regarded as negligible. There are signs of the influence of both European Community and Human Rights Law in the decision.

There must scarcely be an area of English law that is untouched by the domestication of European Human Rights Law. Financial services law might be seen as a rare exception. The Three Rivers case shows how untrue this is. Procedural guarantees enshrined in Article 6 have already made their mark on the architecture of financial services regulation, ${ }^{98}$ and it would seem that their effect is being felt in the most recent Three Rivers judgment. In the judgments of the majority in the House of Lords concerning the improper use of the Bingham Report, repeated reference is made to the claimant's right to a fair trial. ${ }^{99}$ Similar concerns are present when Lord Hope expresses his hesitance in striking out claims concerning complex issues of fact and law without examination at trial. An explicit analogy was drawn with the right to a fair trial guaranteed by Article 6 of the European Convention when emphasising the overriding objective of the new procedural rules. ${ }^{100}$ Moreover, a statutory immunity will of course be subject to a proportionality review under Article 6 ECHR. ${ }^{101}$

Also, Community law influences can be detected within Lord Hope's judgment. In various key areas of his judgment, he acknowledged the influence of European law in shaping the elements of the cause of action. In response to the fact-sensitive issue of the degree of risk of which the regulator must have been aware, Lord Hope instinctively latched upon the test of a sufficiently serious risk of loss. ${ }^{102}$

Supranational law is not the extent of potential European influence in this sphere. Developments at a national level in European jurisdictions may also

98 J McDermott, 'Commercial Implications of the Human Rights Act 1998' (2000) BJIBFL $449,453$.

99 Three Rivers District Council [2001] UKHL 16, para 6 (Lord Steyn), 33 and 80 (Lord Hope).

100 Three Rivers District Council [2001] UKHL 16, para 92.

101 See, for instance, the recent decision by the European Human Rights Court in Al-Adsani v United Kingdom, Application no 35763/97, judgment of 21 Nov 2001.

102 Three Rivers District Council [2001] UKHL 16, paras 60 and 76. 
have a role to play. The international and cross-jurisdictional nature of the regulation of banks makes this sphere, as we have already seen, particularly open to the influence of comparative law.

\section{B. Role of Misfeasance in Governmental Liability}

In controlling governmental wrongdoing, the tort of misfeasance has generally been distinguished from other torts by the need to show egregious intentional wrongdoing. This high level of required fault has limited its attractiveness to potential claimants who have instead preferred to rely upon the torts of assault, false imprisonment, and more particularly, negligence.

A consideration of the future role for the tort of misfeasance must be placed in the context of the broadening of its constituent elements; developments which we have already examined above. Misfeasance is now an intentional tort for which recklessness suffices. Although the form of recklessness proscribed in the recent cases is not objective, as some awareness on the part of the defendant would seem to be required, the gap between this tort and the tort of negligence, premised upon the all-pervading notion of reasonable foreseeability, has undoubtedly been narrowed.

This broadening of the mental element of the tort of misfeasance is not the only explanation for its enhanced appeal to litigants. Three further points should also be made.

\section{Requirement of Proximity}

In order to succeed in an action based upon the tort of negligence, the claimant must show that he or she was in a proximate relationship with the defendant. This can prove to be a significant obstacle to recovery. ${ }^{103}$

The exact role of proximity within the tort of misfeasance has been contested. In the Court of Appeal decision in Three Rivers, the majority indicated that proximity was of relevance to misfeasance in public office, ${ }^{104}$ that it might play a limiting role where the number of claimants was large and alleged 'range of duty' was wide. ${ }^{105}$ However, the House of Lords took a different view. The Court of Appeal's approach to proximity was rejected by Lord Steyn and Lord Hutton. ${ }^{106}$

This might make the tort of misfeasance in certain circumstances a more realistic option to claimants than the tort of negligence, particularly where the class of the potential claimants to which a duty of care in negligence would be owed is very broad. Indeed, in the case of banking supervision, the common law approach of the courts to negligence claims has been restrictive. In a

103 See, eg, Capital \& Counties plc v Hampshire County Council [1997] QB 1004.

104 Three Rivers District Council [1999] EuLR 211, 270-2 (CA).

105 Ibid, 270.

106 Three Rivers DC v Bank of England [2000] 2 WLR 1220, 1233 and 1267. 
number of cases, it has been held that regulators owe no duty to depositors for want of proximity. ${ }^{107}$ So, no duty may arise at common law, even if the regulators are shown to have acted in flagrant breach of their official duties. In such circumstances, misfeasance presents an alternative action against the wrongdoers. There will no doubt be other areas of public authority activity in which proximity has traditionally posed an obstacle to recovery in damages on the basis of negligence, and in which misfeasance in public office may therefore provide a remedy for instance in actions against the police.

\section{The Recovery of Economic Loss}

The reluctance of the courts to allow the recovery of pure economic loss for negligent wrongdoing is well known. There are important developments in most jurisdictions, and since Brasserie du Pêcheur $v$ Germany and Factortame No 4 it has been clear that liability for breach of Community law cannot be limited to certain, individually protected individual interests. ${ }^{108}$ However, other than in restricted circumstances, the English courts preclude the recovery of financial loss that is unconnected with physical damage to the claimant's person or property. ${ }^{109}$

Reluctance to allow claims concerning pure economic loss is one of the reasons for which the actions in negligence against financial regulators have foundered in English law. ${ }^{110}$ However, this policy of caution has not-as yet-been extended to the tort of misfeasance in public office. It is no coincidence therefore that many of the leading misfeasance cases concern economic loss, ${ }^{111}$ of which Three Rivers is an example par excellence. Although the size and extent of the loss suffered by the BCCI depositors may have had some impact on the framing of the tort in Three Rivers, it certainly did not have an exclusionary effect. This characteristic of the tort might draw its attention to those who traditionally would have difficulties in availing themselves of a negligence claim, such as disappointed applicants for commercial licences, or those who have suffered loss due to adverse planning decisions.

\section{Exemplary Damages}

In exceptional cases, the English courts can award punitive damages that are

107 In the regulatory sphere, see Yuen Kun Yeu v Attorney General of Hong Kong [1988] AC 175 (Privy Council); Cooper v Hobart, 2001 SCC 79 (Supreme Court of Canada).

108 See the judgment of the European Court of Justice in Brasserie du Pêcheur v Germany [1995] ECR I-1029, at para 90, [1996] QB 404, at 504.

109 The major exception to this is the rule laid down in the case of Hedley Byrne \& Co Ltd $v$ Heller \& Partners [1964] AC 465.

110 See references to the spectre of indeterminate liability in Cooper v Hobart, 2001 SCC 79 (Supreme Court of Canada).

111 Bourgoin SA v MAFF [1986] QB 716; Roncarelliv Duplessis (1959) 16 DLR (2d) 689 (Canadian Supreme Court). 
designed to express the court's disapproval of the defendant's exceptionally bad conduct. ${ }^{112}$ Until recently, the award of exemplary damages was limited by means of the 'cause of action test', restricting the grant of such damages to those causes of action for which exemplary damages have been awarded prior to the case of Rookes $v$ Barnard ${ }^{113}$ in $1964 .{ }^{114}$ This rule precluded the award of such damages for negligence, ${ }^{115}$ breach of statutory duty, ${ }^{116}$ and misfeasance in public office. However, in a recent case the House of Lords refused to strike out an action for the award of exemplary damages for misfeasance in public office, rejecting the 'cause of action test' as a limiting factor upon the award of such damages. ${ }^{117}$

It is not entirely clear what the position now is in respect of the other torts that previously were not eligible for the award of punitive damages. Should the position remain that negligence is excluded, then there would be an added reason for bringing an action in misfeasance: the potential for a greater quantum of damages.

\section{CONCLUSION}

The House of Lords judgment in Three Rivers is an important one for the domestic law of governmental liability. It is illustrative of a gradual liberalising of the conditions for state liability that has been a feature of recent cases on the tort of negligence. ${ }^{118}$

We have seen that liability for financial market supervisors is under discussion in several EU member states, and there are recent developments in the case law and legislation of a number of member states including France, Germany, and Italy. The House of Lords made no reference to any of this. ${ }^{119}$ Neither did it make any reference, in the discussion of the system of the rele-

112 Rookes v Barnard [1964] AC 1129.

113 Ibid.

114 See $A B v$ South West Water Services Ltd [1993] QB 507.

115 Ibid.

$116 R v$ Secretary of State for Transport ex p Factortame (No 5), [1998] EuLR 456 (CA).

117 Kuddus $v$ Chief Constable of Leicestershire Constabulary [2001] 2 WLR 1789.

118 See, in particular, Barrett v Enfield LBC [2001] 2 AC 550; Phelps v Hillingdon LBC [2001] 2 AC 619.

119 But the House of Lords extensively discussed cases from different Commonwealth jurisdictions. They are recognised as persuasive authorities. Lord Bingham foresees that judgments from other European countries will be dealt with in a similar way, see for instance his highly convincing and elegant argument in 'A New Common Law for Europe', in BS Markesinis, The Coming Together of the Common Law and the Civil Law. The Clifford Chance Millenium Lectures (Oxford: Hart Publishing, 2000), 27, and in Fairchild [2002] UKHL 22, para 32, where, in para 168, also Lord Rodger comments on the use of comparative law. A predecessor as Senior Law Lord, Lord Goff of Chieveley introduced a use of comparative legal materials in the House of Lords which today is more extensive than in any other European court. But not in the present case. There is an extensive and interesting discussion of fault as an ingredient of tort liability for public authorities in different member states by AG Tesauro in Brasserie du Pêcheur v Germany [1995] ECR I-1029, [1996] QB 404, at para 85-90. 
vant directive, to the systems of banking supervision in other member states, with one exception. ${ }^{120}$

It is unfortunate that account was not taken of the European developments. The cases from other national European jurisdictions indicate a perceptible shift towards a more liberal approach to actions brought by investors. The French courts have recognised liability of the regulator, the Commission bancaire, whilst still maintaining a strong protection at the fault level. The Italian courts have extended their case law in favour of governmental liability for inadequate supervision in the sphere of financial supervision. The German doctrinal critique of the 1984 legislation, limiting the case law in favour of depositors, has become increasingly vocal.

The comparative law material could serve a number of purposes. This backdrop of European cases may perhaps assist in the comprehension of the developing English case law. The developments in the House of Lords are not taking place in isolation: they are occurring within a broader European trend of expanding public law and tort law remedies.

The comparative law dimension is not only helpful in allowing one to place the English developments in a wider context. It may also provide practical guidance for the domestic courts. In particular, the French litigation allows one to challenge the assumption that changes at the fault level may result in uncontrollable extension of liability in general. The approach of the French administrative courts illustrates a creative attitude to the control mechanisms in these cases. In particular, the doctrine of loss of a chance may well be a useful tool for the English courts in evaluating the quantum of loss suffered by depositors. Although the courts have been reluctant to apply this doctrine in personal injury cases for lost chances of recovery, ${ }^{121}$ there have been a number of successful damages actions for the lost opportunity of financial gain, ${ }^{122}$ in spheres a diverse as lost employment opportunities, ${ }^{123}$ and loss of opportunity to bring civil proceedings. ${ }^{124}$ Comparative material could serve other purposes. It could provide a better understanding of the supervisory regime under the two banking directives in force at the relevant time. This is of course crucial for the determination of liability under Community law.

120 This one exception is the statement about there being no supervisory authorities in the UK or Denmark before the First Banking Directive [2000] WLR 1220 at 1254. It is based on a factual misunderstanding.

121 Hotson v East Berkshire Area Health Authority [1987] AC 750.

122 Allied Maples Group Ltd v Simmons \& Simmons [1995] 1 WLR 1602. See Lunney and Oliphant, Tort Law: Text and Materials (Oxford: Oxford University Press, 2000), 184; Markesinis and Deakin, Tort Law, 4th edn (Oxford: Oxford University Press, 1999), 183. See also the discussion of Community law rights to compensation for 'lost profits' and in particular the relevant French law by AG Tesauro in the Brasserie du Pêcheur v Germany [1995] ECR I-1029, [1996] QB 404, at para 91-6.

123 Spring $v$ Guardian Assurance [1995] 2 AC 296, 327.

124 Kitchen v Royal Air Force Association [1958] 1 WLR 563. 